\title{
Stock Market Rationale under Conditions of Defective Corporate Governance - The Case of Macedonia
}

\author{
Sasho Arsov \\ Faculty of Economics, Ss. Cyril and Methodius University, Skopje, Macedonia \\ E-mail: sarsov@eccf.ukim.edu.mk
}

\section{Doi:10.5901/mjss.2013.v4n2p301}

\section{Abstract:}

The goal of this paper is to examine the real role of the stock market in an economy with a specific legacy from the transition period. Macedonia emerged as one of the successors of former Yugoslavia and after a period of transition to a market economy, it became evident that the expectations for a fast convergence with the developed economies did not materialize. One of the reasons for this disappointment lies in the defective corporate governance structure that was created through the privatization in which most of the potentially successful companies were bought by their employees and managers. In such a situation, the dominant owners show little interest in disclosing details from their companies to the public, they find different ways to extract benefits from the business for themselves by bypassing the stock market, the efforts of the managers are not reflected in the share prices, etc. In such circumstances, the investors in shares are trying to pick potential "winners" rather than analyze the company fundamentals and the stock exchange resembles a casino to a much greater extent than we are ready to admit.

\section{Introduction}

In the beginning of the 1990s the process of mass privatization in Eastern Europe was initiated with the widespread belief that the transformation of ownership from the state into the hands of known and motivated owners would bring economic efficiency, GDP growth and higher standards of living for the whole population. At that time, almost no attention was being paid to the issue of corporate governance since it was assumed that the change of the title-holder of the companies' assets should be a sufficient condition for their transformation into western-style competitive corporations.

Two decades later, it became clear that Macedonia, as well as the other countries in the region did not make a great progress in terms of their GDP growth, or at least they did not move far away from their pre-transition levels. This is especially true for the countries which were not flooded by foreign direct investments like Poland, Hungary or the Czech Republic, for example. One of the reasons for this unsuccessful story are the war conflicts which overwhelmed the region in the nineties, but we assume that another very important element in the picture is the system of corporate governance prevailing in these countries, which is again a result of the process of privatization that they have gone through.

In Macedonia, the unfortunate privatization process resulted in a widespread insider ownership by both managers and employees. This created a set of complex relationships in which the employees-shareholders act as controllers of the managers and at the same time depend on them to maintain their regular jobs.

In this paper, the effects of the privatization are not our direct concern. Here we are mostly interested in the rationality of the stock exchange's operations, even of its mere existence, and the judiciousness of the investors trying to earn money trading shares in an illiquid market which has barely any connection with the real occurrences in the economy.

In order to give answers to these questions, we will try to outline the most important characteristics of the system of corporate governance in Macedonia. From these characteristics, we will deduct our conclusions regarding the real benefits of a capital market for a small economy with an ownership structure created through a process of enforced privatization based on the autonomy of its participants. We believe that the conclusions from this paper will be transferrable to a number of comparable economies in the region, which have undergone through similar processes. 


\section{The corporate objective dilemma and its relevance in Macedonia}

The issue of aligning the interests of the companies' managers to those of their shareholders is the root of the whole corporate governance theory. In practice this can be achieved if the company adopts a goal related to the satisfaction of the shareholders and the managers are sincerely dedicated to fulfill it. According to the theory at least, the goal of the company is to maximize the shareholders wealth through the maximization of the market value of its shares. This view is supported by many leading scholars in the area of corporate governance (Jensen, 2002; Sundaram et al., 2004), in numerous textbooks (Reilly and Brown; Ross, Westerfield and Jaffe; Damodaran (various editions), etc.), but it is also confirmed in the practice of the US companies through the CEOs' addresses to their shareholders in the companies' annual reports. This view and the concern with the shareholders' interests are mostly present among the US and UK companies, while their counterparts from continental Europe and Japan follow a somewhat different approach in setting their priorities. The so-called stakeholder theory (Freeman, 1984; Mitchell, 1997; Clarkson, 1995; Jones et al., 1999) is considered to better represent the reality in these economies where the companies are expected to work in the interests of their employees, the community, their customers and suppliers, etc. Although it is very dubious to which extent this concept is implemented in reality, it is widely criticized for the built-in flaw that there is no single measure of satisfaction of all these diverse interests, so that it cannot serve the purpose of stimulation of greater efficiency.

It is not our goal to try to resolve this dilemma. We are only briefly referring to the two most prevailing views in the corporate objective issue in order to shed more light on the behaviour of the Macedonian managers and their relations with the shareholders.

For this purpose, we have examined the statements given by the Macedonian companies through their websites, annual reports, mission and vision statements to implicitly derive their attitudes toward the maximization of shareholders' wealth. The analysis has shown that out of the 29 listed companies under our consideration only 5 are preparing annual reports for the shareholders. The others are preparing and publishing only short reports containing only operating information. Regarding the corporate goals, we have derived them from the websites directly, if observable, or from the annual and other reports, where available. In only 2 of the cases, the company goals contain some reference to the shareholders' wealth, although vaguely, while in 4 cases the goals are broader, targeting several different groups, so that we can consider them followers of the stakeholder theory. In 4 other companies, the corporate goals are defined in the form of operating goals. Only 14 of the analyzed companies have a section related to Investor relations on their websites. It is interesting that the analysis encompasses 5 companies with dominant foreign shareholders.

Therefore, the general conclusion would be that the companies do not pay much attention to the specification and publication of their overall objectives, and when they do, they almost never relate these objectives to the interests of their shareholders.

\section{The ownership structure of the listed companies in Macedonia}

The corporate governance systems in the post-transition economies have been predominantly shaped by the approach to privatization these countries have adopted. These approaches moved from case-by-case to mass privatizations and from voucher schemes to paid privatizations. Macedonia was a part of former Yugoslavia in which the process of privatization began very early in 1989, but was later interrupted and afterwards it continued in the independent Republic of Macedonia under its specific legislation.

The first wave of ownership transformation was legally grounded on the Law on trade and possession of social capital which came into force in 1989. The concept of privatisation of the last Yugoslav government was based on both the principles of bottom-up privatisation (creation of new private firms) and top-down privatisation (sale of the existing "social" enterprises to their employees or other interested parties).

However, the opportunity to buy shares at a discount, as well as some distortions in the implementation of other regulations, especially those concerned with the payment of salaries, almost malformed the concept into a process of free privatisation. Very often, the managers and employees would find a way for a fictitious increase of their salaries which were used to pay for the subscribed shares. In this manner, they could obtain a high percentage of ownership of their companies by paying only a negligible sum of money.

The second stage of the privatisation in Macedonia began with the enactment of the Law on transformation of enterprises with social capital. After a long political debate and a lot of consultancy, the law was finally adopted in June 1993. 
The selected concept was that of paid privatisation. With the aim of providing financial resources, much needed for the transitional period, the political leadership decided to apply a concept of sale of the enterprises under a prescribed procedure. This was a kind of a bottom-up approach, where the decision for privatisation, the choice of the method of privatisation and a great deal of the privatisation procedure were left to the enterprises themselves. However, the law stipulated that the privatisation was obligatory and that the procedure had to be initiated within a given period of time. In order to provide the necessary administration and support for the process, the Agency of the Republic of Macedonia for the Transformation of Enterprises with Social Capital was established in October 1993.

The first wave of privatization resulted in the creation of large ownership stakes by the employees and managers in many Macedonian companies. To make things worse, in Macedonia this process went much further than in all the other former Yugoslav republics, later independent states. The total percentage of private equity in Macedonia reached about $19 \%$ of the total capital, while the average for Yugoslavia was 10\% (Nedkov et al., 1991). This was a huge obstacle for the second stage, when the companies were not open for free entry of other investors, which was further complicated with the abovementioned independence of the companies in this process. This gave the incumbent managers the chance to shape the process in a way that would be most suitable for them to keep their control over the companies.

An obvious result of this situation is the dominance of the methods Employee Buy-Out and Management Buy-Out, which, when implemented under conditions of $40-50 \%$ of previously privatized equity, gave little chance to outside investors to enter the process of privatization. The following table illustrates this point.

Table 1: Privatised companies by method of privatisation at each year-end (cumulative figures)

\begin{tabular}{|l|c|c|c|c|c|c|c|c|}
\hline Method of privatisation & $\mathbf{1 9 9 5}$ & $\mathbf{1 9 9 6}$ & $\mathbf{1 9 9 7}$ & $\mathbf{1 9 9 8}$ & $\mathbf{1 9 9 9}$ & $\mathbf{2 0 0 0}$ & $\mathbf{2 0 0 1}$ & $\mathbf{2 0 0 2}$ \\
\hline Privatised by the old law & 59 & 65 & 66 & 67 & 66 & 66 & 66 & 65 \\
\hline Employee Buy-Out & 210 & 301 & 331 & 363 & 384 & 395 & 394 & 394 \\
\hline Sale of a part of the company & 12 & 23 & 35 & 59 & 67 & 143 & 185 & 196 \\
\hline Management Buy-Out & 42 & 123 & 190 & 253 & 247 & 240 & 239 & 236 \\
\hline Leasing & 3 & 4 & 4 & 4 & 4 & 4 & 4 & 4 \\
\hline Additional investment & 5 & 14 & 16 & 19 & 20 & 25 & 27 & 27 \\
\hline $\begin{array}{l}\text { Transfer of residual shares to the } \\
\text { Privatization Agency }\end{array}$ & 11 & 35 & 27 & 26 & 28 & 28 & 28 & 29 \\
\hline Debt/Equity Swap & 1 & 15 & 36 & 63 & 75 & 85 & 91 & 93 \\
\hline Acknowledgment of foreign equity & 153 & 154 & 156 & 156 & 156 & 155 & 155 & 155 \\
\hline Acknowledgement of private equity* & 60 & 55 & 95 & 113 & 128 & 135 & 142 & 143 \\
\hline Bankruptcy - Liquidation $^{*}$ & 33 & 38 & 48 & 164 & 164 & 166 & 169 & 169 \\
\hline Company Buy-Out & 15 & 87 & 128 & 148 & 149 & 173 & 178 & 177 \\
\hline TOTAL & 604 & 914 & $\mathbf{1 . 1 3 2}$ & $\mathbf{1 . 4 3 5}$ & $\mathbf{1 . 4 8 8}$ & $\mathbf{1 . 6 1 6}$ & $\mathbf{1 . 6 7 8}$ & $\mathbf{1 . 6 8 8}$ \\
\hline
\end{tabular}

Source: Macedonian Privatisation Agency - Annual Reports (1995-2002)

(*) Some of the methods require explanation:

- Privatised by the old law (1989-91) - these companies were privatised 100\% by the Laws from 1989 and 1990.

- Acknowledgment of foreign equity - some companies were founded by foreign companies (mostly from the ex-Yugoslav republics), so that this ownership was acknowledged and accepted as partial or completed privatisation.

- Acknowledgement of private equity - same as before, with the only difference that a former private stake from the period of nationalization (1946-48) was discovered in the process of privatisation and accepted as such.

- Bankruptcy - Liquidation - some companies encountered financial difficulties and were liquidated.

NOTE: The lower cumulative figure compared to that of the previous year are a result of the cancelation of some privatisations.

After this, the ownership structures of the companies have changed as a result of the secondary trading. Most often, this resulted in higher concentration of ownership in the hands of the dominant investors. In the sample of 29 
companies listed on the stock exchange there are 9 in which the insiders-managers own between $10 \%$ and $33 \%$ of the shares. These owners exercise effective unopposed control over the companies mostly because a huge percentage of the remaining shares belong to the employees. They are not in a position to act as real shareholders, since they depend on the same managers to keep their jobs, which, in a country with $32 \%$ unemployment is much more important than being an active shareholder and investor. Among the remaining companies, in 7 of them there are dominant foreign investors possessing between $16 \%$ and $100 \%$ of the shares. ${ }^{1}$

\section{Transparency and disclosure}

Another important aspect of corporate governance is the level of transparency of the companies. We will describe this feature of the corporate governance system in Macedonia to illustrate the companies' attitudes in dealing with their investors.

Good corporate transparency together with high quality disclosure is widely accepted as one of the pillars of good corporate governance. It is believed that investors need to have all the relevant information to be able to make appropriate decisions determining the future of the company. Transparency brings benefits for the company through its impact on company valuation, cost of capital, access to external financing, etc. (La Porta et al. (2002); Verrecchia (2001); Frost et al. (2005); Botosan (2006); Hail (2002), among others). On the other hand, the company insiders have both legitimate and private reasons to believe that not everything should be disclosed to the public. They strive to protect their own positions, but also the position of the company vis-à-vis its competitors, which opens a dilemma regarding the costs and benefits of transparency (Hermalin and Weisbach (2007), Verrecchia (2001)).

For this purpose, we have used the scoring methodology developed by Standard and Poor's (described in Patel et al. 2002). The procedure is based on the observation of the companies' annual reports and it attempts to determine the level at which the companies provide the public with the information necessary for making investment decisions and effective corporate governance. This information is divided into three areas: Ownership, Financial disclosure and Board and management.

For the purposes of the study, we have made some adjustments to the procedure. Namely, the number of Macedonian companies producing annual reports in their classical format is negligible. Therefore, we have used all the reports the companies are disclosing both in their own websites and through the Macedonian Stock Exchange website. These reports include the audited financial statements with the auditors' reports, shareholders assembly invitations and agendas, dividend calendars, etc.

In our research, we have focused on the companies listed on the MSE, which makes a sample of 29 companies. (We have intentionally omitted 2 of the listed companies, because they are undergoing a recovery program). Although the sample might seem too small, one should have in mind the overall size of the Macedonian economy and that the shares of these companies accounted for more than $40 \%$ of the total number of transactions on the stock market in 2011).

The study has shown that the composite S\&P transparency score for the Macedonian companies is 35 . Using the results from the S\&P study from 2001, this result is comparable only with the score for Latin America (31), but it is much lower than the average European score of 58 at that time. By groups of questions, the highest score for Macedonia is achieved in the area of financial disclosure -54 . It is obviously a result of the requirements for mandatory disclosure for all the public companies. On the other hand, the score is very low in the field of board and management structure and processes. The score for this item is only 10 , while the same average score for Europe is 51 . When interpreting these results, we must always have in mind that the S\&P study was made more than a decade ago, so that the respective scores should be higher today.

The other interesting findings from the research on the Macedonian companies are the following:

- The companies differ widely in terms of how much they disclose. The scores vary between 19 and 53. Also, a number of companies have a score of 0 in the area of board and management, i.e. there is no information available about the composition of their governance and management structures at all.

- The overall transparency score is increased due to the presence of banks in the sample. Their scores are much higher on average than the composite result for the entire sample. This is an expected outcome, since the banks must additionally follow the central bank's supervision requirements and are obliged to prepare much more detailed reports.

\footnotetext{
${ }^{1}$ Here we have included only the ownership which is disclosed and publicly available through the Central Depository website, which publishes only ownership stakes of5\% or more. This opens an opportunity of even larger stakes held under other forms (indirectly, through managers' own private companies or through relatives holding less than $5 \%$ ).
} 
- Another conclusion which can be drawn from the research is that having a dominant foreign owner or a significant ownership share by an investment fund or an institutional investor like EBRD is beneficial for the company's transparency. Among the top 12 rated companies according to the TD score, there are 4 with a dominant foreign owner (with at least $55 \%$ stake), one with a significant EBRD share $(25 \%)$, one with a $16 \%$ foreign investment fund stake and one with a combined EBRD/Investment fund share of $15 \%$ in total.

A general conclusion can be deducted: the non-bank companies without significant foreign ownership are not very eager to disclose to the public the information related to their businesses.

\section{The functioning of the Macedonian Stock Exchange}

In the mid-nineties, as the process of privatization was gaining speed, the need to provide an opportunity for secondary trading was recognized. The Macedonian Stock Exchange (MSE) was established in 1995 and its operations began in the spring of 1996. During the first several years, the activity on the exchange was more than apathetic. The turnover was negligible, with numerous days with no trading at all. The attitude of the companies toward the role of the secondary market is illustrated by the fact that the number of listed companies on the so-called first market was only 2 as of year 2002. Not disregarding the low listing fee requirement, the main reason for this was the fear from disclosing too much information to the public. In order to boost the stock market, in an unusual move the Government introduced mandatory listing for the companies that fulfilled certain conditions. This led to the increase of the number of listed companies to 98 by the end of 2003 and it had a very strong impact on the companies' transparency and the investors' confidence. Several years later, this obligation was removed and a number of companies have withdrawn from listing since then.

This general attitude of the largest companies toward the stock market had a strong impact on the way it was perceived by the investing public. There was almost no demand for the shares, in spite of the bargain prices at which they were offered on the market. This was confirmed several years later, when the positive sentiment and the abundant monetary influx from foreign investors during the booming phase of the last business cycle spilled over into the country and capital gains amounting to as much as $1.000 \%$ per share for a period of 2-3 years were not unusual.

When the boom was over, the market dropped as fast as it soared several years before. The market index fell from above 10.000 to a low of 1.600 points. The fall in the market turnover was even more dramatic. After a period in which it amounted to above EURO 5 million in a single day, it dropped to a less than EURO 200.000 per day. We point this out to demonstrate that a small market like this is mostly driven by external and random forces and it can hardly be used as a measure of the health of the economy. Therefore, numerous pieces of information that these markets provide to the investing public, the analysts and to the companies are useless in such situations.

The table below provides an illustration of the annual turnover with shares in classical trading (block trades excluded) and the MSE index in the last 11 years. It clearly shows that after a short period of market boom, both the turnover and the index returned to their "normal" levels.

Picture 1: Turnover and market index on the Macedonian Stock Exchange by years

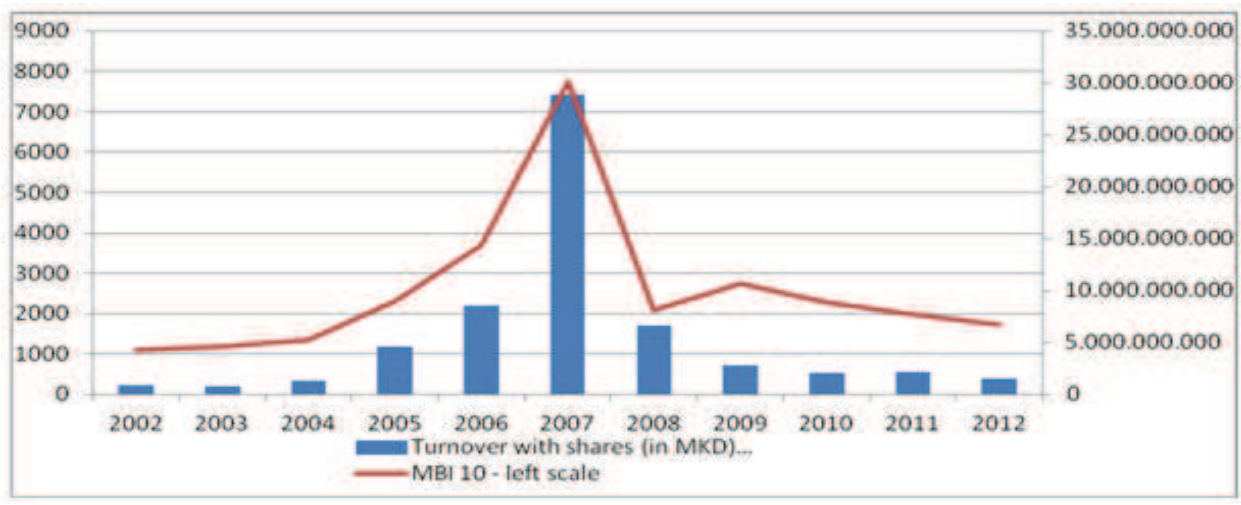

Source: Macedonian Stock Exchange - Annual Bulletins 
It is indicative that in spite of the general undervaluation of the companies (based on their market multiples), not a single CEO has been removed from its position for this reason. In addition to this, it is worth mentioning that there are also no examples of manager compensation linked to the market valuations. On one hand this is understandable when the market valuations only slightly depend on the managers' efforts, but on the other hand it proves that there is no accountability for the managers when the shareholders' interests are concerned. From an investor's point of view, this is a terrifying conclusion.

\section{Concluding remarks}

The goal of this paper was to illuminate the position of the investors in the stock market of a small economy with a vague relationship between the company fundamentals and the respective share price. The features of the corporate governance and the capital market in Macedonia presented above which are relevant for our goal, can be summarized as follows:

- Maximization of shareholder wealth through maximization of the value of the company is rarely, if ever, recognized as a corporate goal. In some cases, inclination toward stakeholders' welfare is obvious. This is perhaps partially a residue from the previous system, when the interest of the entire community was given priority above individual interests and the people are still not ready to change their mindsets toward implementing a more individualistic approach;

- The listed companies show very little interest in voluntary disclosing important information to shareholders;

- In most of the companies, insiders (both managers and employees) hold a dominant ownership stake;

- In the illiquid stock market, there is no direct relationship between the managerial efforts and the share price. The managers are not stimulated to work in the best interest of the minority shareholders, and since they are often the dominant shareholders, they can easily align their own interests as shareholders and managers, mostly bypassing the stock market, etc.

As a result of these features, we can say that there is a defective corporate governance system in place with the following characteristics:

- There is no real separation between the ownership and management of the company. Numerous companies function as private, although they are officially public and listed on the stock exchange;

- A large portion of the shareholders at the same time act as controllers and subordinates to the company managers;

- Transparency is considered more a burden, rather than a need and its benefits are disregarded. Perhaps this is normal in the case of closely held companies;

- The capital market is not a real arbitrator of the occurrences in the corporate sector. It neither rewards, nor it penalizes the behaviour of the company managers;

- The companies' objectives are vague and they are definitely not related to the stock market.

All of the above brings us to the conclusion that the movements on the stock exchange are barely related to what happens in the economy. It makes the use of all the known valuation, portfolio management and other investment planning techniques troublesome. The investors are left to work in the darkness, using a lot of intuition and rumors rather than official information, which, in a small country is easily being spread. Instead of fundamental analysis and sciencebased techniques, the use of technical analysis and the knowledge of behavioral finance become an advantage.

At the same time, this opens the question of the real raison d'être for the stock market. It is a necessity for the sake of secondary trading with the securities, but...does it really perform its basic function of allocation of funds under such circumstances? Does it serve as a means for assessment the quality of the managerial actions? Does it protect the interests of minority shareholders? Does it provide the shareholders with the needed information? If the answers to these questions are no, the entire format of its functioning becomes susceptible and instead of trying to apply or adjust the theories developed in the older market economies, a new doctrine should be developed to better match the reality in these countries.

\section{References}

Botosan, Christine A. (2006). Disclosure and the cost of capital: what do we know?. Accounting and Business Research, Intemational Accounting Policy Forum, pp. 31-40.

Bradley, M., Schipani, C. A., Sundaram, A. K. \& Walsh, J. P. (1999). The purposes and accountability of the corporation in contemporary society: Corporate governance at a crossroads.Law and Contemporary Problems, 62, 3: 9-86 
Clarkson, M.B.E. (1995). A stakeholder framework for analyzing and evaluating corporate social performance. Academy of Management Review, 20: 92-117.

Fama, E. F. \& Jensen, M. C. (1983). Agency problems and residual claims. Journal of Law and Economics, 26:325-344.

Freeman, R. Edward. (1984). Strategic Management: A Stakeholder Approach. Pittman Books Limited.

Frost, C. A., E. A. Gordon, G. Pownall. (2005). Transparency, Disclosure, and Emerging Market Companies' Access to Capital in Global Equity Markets., SSRN Working Paper, http://papers.ssrn.com /sol3/papers.cfm?abstract_id=802824

Hail, L. (2002). The impact of voluntary corporate disclosures on the ex-ante cost of capital for Swiss firms. The European Accounting Review, 11 (4):741-773.

Hermalin, B. and M. Weisbach. (2007). Transparency and Corporate Governance. NBER Working Papers 12875.

Jensen, C. Michael. (2002). Value Maximization, Stakeholder Theory, and the Corporate Objective Function. Business Ethics Quarterly, Vol. 12, No. 2

Jones, T. M. \& Wicks, A. C. (1999). Convergent stakeholder theory. Academy of Management Review, 24: $191-205$.

La Porta, R., F. Lopez-de-Silanes, A.Shleifer and R. Vishny. (2002). Investor Protection and Corporate Valuation. Journal of Finance, Vol. LVII, No. 3

Mitchell, R. K., Agle, B. R., \& Wood, D. J. (1997). Toward a theory of stakeholder identification and influence: Defining the principle of who and what really counts. Academy of Management Review, 22: 853-886.

Nedkov, Milan et al. (1991). Privatizacija na opstestveniot kapital vo Republika Makedonija - studija (Privatisation of the Social Capital in Macedonia - a study). Skopje, Macedonia: Faculty of Law.

Orazem, Peter F., Vodopivec, Milan. (2004). Do market pressures increase economic efficiency? The case of Slovenian manufacturing, 1994-2001. Washington D.C.: World Bank Policy Research Working Paper 3189.

Patel, S., A. Balic, G. Dallas. (2002). Transparency and disclosure: Overview of methodology and study results-United States, Working paper, Standard and Poor's and SSRN, http://ssrn.com/abstract=422800

Sachs, J., Zinnes, C., Eilat, Y. (2000). The Gains from Privatisation in Transition Economies: Is Change of Ownership Enough?. Cambridge, MA: CAER II Discussion Paper No. 35.

Sundaram, A. K. \& Inkpen A. C. (2004). The Corporate Objective Revisited. Organization Science, Vol. 15, No. 3, pp. 350-363

Verrecchia, R. (2001). Essays on Disclosure. Journal of Accounting and Economics32, 97-180

West, M. D. (2001). Why shareholders sue: The evidence from Japan. The University of Chicago Journal of Legal Studies, 30: 351-382. 
